\author{
SHAMILOV E.N. ${ }^{1 凶}{ }^{\square}$ ABDULLAEV A.S. ${ }^{1}{ }^{1}$, FARAJOV M.M. ${ }^{1}$ SHAMILLI V.E. ${ }^{1}$, \\ GAHRAMANOVA SH.I. ${ }^{2}$, JALALADDINOV F.F. ${ }^{2}$ \\ ${ }^{1}$ Institute of Radiation Problems of ANAS, \\ Azerbaijan Republic, AZ1143, Baku, B. Vahabzadeh, 9, e-mail: elshanshamil@gmail.com \\ ${ }^{2}$ Institute of Catalysis and Inorganic Chemistry ANAS, \\ Azerbaijan Republic, AZ1143, Baku, Huseyn Javid ave., 113 \\ 凶elshanshamil@gmail.com
}

\title{
SYNTHESIS, CHARACTERIZATION AND ANTIRADIATION PROPERTIES OF THE TRYPTO- PHANATES OF COBALT (II), MANGANESE (II), COPPER (II) AND ZINC
}

\begin{abstract}
Aim. In order to study the radioprotective activity were were obtained in the tryptophanates of cobalt (II), manganese (II), copper (II) and zinc. Methods. The composition and structure of the complexes were studied by elemental, thermogravimetric analyzes and IR infrared spectroscopy. To determine the presence of the Radioprotective Properties of the Co (II), Mn (II), Cu (II), Zn complexes with tryptophane, a test was conducted for the 30-day survival of irradiated animals. Results. The results of thermogravimetric studies have shown that the final product of the thermal decomposition of all compounds is metal oxide, respectively. The method of IR spectroscopy showed that the ligands in the composition of the metal (II) complexes enter the neutral form and coordinate with the complexing agent through the nitrogen atom. The results of experiments with complexes showed that they have noticeable radioprotective activity. The radioprotective activity of Co (II) complexes with tryptophan is $55 \%$, Mn (II) with tryptophan $50 \%, \mathrm{Cu}$ (II) with tryptophan $40 \%$, and $\mathrm{Zn} 30 \%$. They improve the survival and average life expectancy of lethally irradiated mice, not reaching the level of the known cystamine radioprotector, which is $80 \%$. Conclusions. The data obtained by us testify to the prospects of using the complexes of Co (II), Mn (II), Cu (II), Zn with tryptophan for preventive purposes and in order to prevent local radiation injuries.
\end{abstract}

Keywords: tryptophan-metal complexes, IR spectroscopy, thermogravimetry, complex compounds, radioprotective properties.

The chemistry of complex compounds of transition metals with multidentate ligands, which simultaneously contain several donor atoms, is not only theoretical but also of practical interest, since in addition to the unusual properties of such com- plexes, the structure and types of binding of multidentate ligands with different metals give a new impetus to the development coordination chemistry as a whole. Among the coordination compounds, the complexes obtained on the basis of biomaterials take a special place. This is due to the fact that they play an important role in many biochemical processes and therefore are widely used in plant growing, animal husbandry, and pharmacology [18]. In turn, the study of the properties and structure of coordination compounds of metal ions with organic ligands containing various donor centers was an important factor in the development of new approaches to their physico-chemical research.

On the other hand, complex compounds of many transition elements can possess a wide range of useful properties, for which the chemistry of complex compounds has not yet been sufficiently studied.

This article presents methods for producing complexes of manganese (II), copper (II), cobalt (II), zinc with a ligand - tryptophan, and also their anti-radiation properties are studied [10].

\section{Material and methods}

Measurement methods: The composition and structure of the complexes were studied by elemental analysis methods (ICP-MS); IR spectroscopy ("Specord M-80" by Carl Zeiss) and thermogravimetric (NETZSCH STA 449F3 STA449FSA0622-M).

\section{Experimental part \\ Synthesis - $\left[\mathrm{CuCl}_{2} \mathrm{~L}\left(\mathrm{H}_{2} \mathrm{O}\right)\right]$}

A sample of $0.85 \mathrm{~g}$ (0.005 mole) $-\mathrm{CuCl}_{2}$ $2 \mathrm{H}_{2} \mathrm{O}$ was dissolved in a two-necked flask under reflux in $30 \mathrm{ml}$ of ethyl alcohol at a temperature of $60^{\circ} \mathrm{C}$, and $1.02 \mathrm{~g}(0.005 \mathrm{~mole})$ of ligand Ltryptophan - (in a molar ratio of $1: 1$ ) previously dissolved in $20 \mathrm{ml}$ of ethyl alcohol. The resulting

\section{○ SHAMILOV E.N., ABDULLAEV A.S., FARAJOV M.M., $\quad$ SHAMILLI $\quad$ V.E. , GAHRAMANOVA SH.I., JALALADDINOV F.F.}


mixture was heated for 2 hours, then cooled to room temperature, filtered and put on crystallization. The blue -colored crystals were filtered, washed several times with the mother liquor, then $15-20 \mathrm{ml}$ with acetone and dried in a desiccator over sulfuric acid until a constant weight was established.

\section{Synthesis - $\left[\mathrm{ZnL}_{2}\left(\mathrm{H}_{2} \mathrm{O}\right)_{2}\right] \mathbf{2 H}_{2} \mathrm{O}$}

To a beige color solution obtained by dissolving $0.32 \mathrm{~g}(0.005$ mole $)-\mathrm{Zn}$ powder in $20 \mathrm{ml}$ of ethyl alcohol, $2.04 \mathrm{~g}$ (0.01 mole) of ligand Ltryptophan dissolved in $30 \mathrm{ml}$ of ethyl alcohol (in a molar ratio 1: 2). The solution was heated for 2-2.5 hours at a temperature of $60^{\circ} \mathrm{C}$. Further, the synthesis process was carried out according to the above described procedure.

\section{Synthesis-[ $\left.\mathrm{MnCl}_{2} \mathrm{~L}_{2}\right] \mathbf{2} \mathrm{H}_{2} \mathrm{O}$}

According to the above procedures, $2.04 \mathrm{~g}$ (0.01 mol) of ligand L- tryptophan (molar ratio 1: 2), previously dissolved in $20 \mathrm{ml}$ of ethyl alcohol, was added to $0.85 \mathrm{~g}$ (0.01 mile) $--\mathrm{MnCl}_{2} \cdot 2 \mathrm{H}_{2} \mathrm{O}$ dissolved in $20 \mathrm{ml}$ of ethyl alcohol. The resulting mixture was heated for 2 hours, then cooled to room temperature, filtered, washed several times with the mother liquor, then 10-15 $\mathrm{ml}$ with acetone and dried in a desiccator over sulfuric acid until a constant weight was established.

\section{Synthesis- $\left[\mathrm{CoCl}_{2} \mathrm{~L}_{2}\right] 2 \mathrm{H}_{2} \mathrm{O}$}

According to the above procedures, $2.04 \mathrm{~g}$ (0.01 mol) of ligand L- tryptophan (molar ratio 1: 2), previously dissolved in $30 \mathrm{ml}$ of ethyl alcohol, was added to $1.17 \mathrm{~g}(0.01$ mole $)-\mathrm{CoCl}_{2} \cdot 6 \mathrm{H}_{2} \mathrm{O}$ dissolved in $20 \mathrm{ml}$ of ethyl alcohol. The resulting mixture was heated for 2 hours, then cooled to room temperature, the purple-colored crystals were filtered, washed several times with the mother liquor, then 20-25 $\mathrm{ml}$ with acetone and dried in a desiccator over sulfuric acid until a constant weight was established.

\section{Results and discussion Elemental analysis}

The elemental analysis data of the metalligand complexes are pointed up in table.

\section{Differential thermal analysis}

With the definition of the thermic stability and the composition of synthesized complexes $\left[\mathrm{MnClL}_{2}\left(\mathrm{H}_{2} \mathrm{O}\right)\right] \mathrm{H}_{2} \mathrm{O},\left[\mathrm{CuCl}_{2} \mathrm{~L}\left(\mathrm{H}_{2} \mathrm{O}\right)\right],\left[\mathrm{CoCl}_{2} \mathrm{~L}_{2}\right] 2 \mathrm{H}_{2}$ $\mathrm{O},\left[\mathrm{ZnL}_{2}\left(\mathrm{H}_{2} \mathrm{O}\right)_{2}\right] \mathrm{H}_{2} \mathrm{O}$ the thermographic analysis was made. Thermogravimetric analysis of the compounds has been conducted in the $25-850^{\circ} \mathrm{C}$ temperature range under nitrogen. The derivatograms of the complexes differ substantially in the nature of the thermal decomposition. Results of thermogravimetric studies have shown that the thermal decomposition of complexes occurs in three stages. The third stage of thermolysis ends with the obtaining of metal oxides.

\section{IR spectroscopy}

To determine the coordination character of the synthesized complex compounds formed between the ligand and of manganese (II), copper (II), cobalt (II) and zinc (II), IR spectroscopic analysis was carried out.

In the IR spectra of complexes the strong and broad absorption band in the range of 3600$3000 \mathrm{~cm}-1$ correspond to asymmetric and symmetric stretching vibrations of aqua molecules. At the range of $3392 \mathrm{~cm}^{-1}$ and $3161 \mathrm{~cm}^{-1}$ bands are belonging to $\mathrm{N}-\mathrm{H}$ stretches of $\mathrm{NH}_{2}$ group of tryptophan. The weak bands at the range of 2936-2906 $\mathrm{cm}^{-1}$ are attributed to the $\mathrm{CH}_{2}$ vibrations. In complexes, tryptophan ligands are coordinated to the metal ion as monodentate by carboxylic group. This claim about the products is supported by FT-IR spectra results. The $\left(\mathrm{COO}^{-}\right)$asym. peaks are located at $1619 \mathrm{~cm}-1$ for $\mathrm{Co}(\mathrm{II}), 1605 \mathrm{~cm}^{-1}$ for $\mathrm{Mn}$ (II), $1625 \mathrm{~cm}^{-1}$ for $\mathrm{Cu}$ (II) and $1622 \mathrm{~cm}^{-1}$ for $\mathrm{Zn}$ complexes.( $\left.\mathrm{COO}^{-}\right)$sym peaks are observed at $1459 \mathrm{~cm}^{-1}$ for $\mathrm{Co}(\mathrm{II}), 1456$ $\mathrm{cm}^{-1}$ for $\mathrm{Mn}$ (II), $1455 \mathrm{~cm}^{-1}$ for $\mathrm{Cu}$ (II) and $1456 \mathrm{~cm}^{-1}$ for $\mathrm{Zn}$ complexes. The low-intensity bands in the region of $600-400 \mathrm{~cm}^{-1}$ are attributed to $\mathrm{M}-\mathrm{N}$ and $\mathrm{M}-\mathrm{O}$ vibration [9].

Table 1. Elemental analysis results of the complexes

\begin{tabular}{|l|l|r|r|l|l|l|l|l|l|}
\hline \multirow{2}{*}{$\begin{array}{c}\text { Symbolic } \\
\text { formula }\end{array}$} & $\begin{array}{l}\text { Molecular } \\
\text { weight }\end{array}$ & \multicolumn{2}{c|}{$\%$ Cl } & \multicolumn{3}{c|}{$\% \mathrm{H}$} & \multicolumn{3}{c|}{$\% \mathrm{~N}$} \\
\cline { 3 - 11 } & & Calc. & Meas. & Calc. & Meas. & Calc. & Meas. & Calc. & Meas. \\
\hline$\left[\mathrm{CuCl}_{2} \mathrm{~L}\left(\mathrm{H}_{2} \mathrm{O}\right)\right]$ & 357 & 19.9 & 19.26 & 3.92 & 3.85 & 6.72 & 6.27 & 17.92 & 17.26 \\
\hline$\left[\mathrm{ZnL}_{2}\left(\mathrm{H}_{2} \mathrm{O}\right)_{2}\right] 2 \mathrm{H}_{2} \mathrm{O}$ & 537 & ---- & ---- & 5.95 & 5.67 & 10.42 & 10.16 & 12.10 & 12.01 \\
\hline$\left[\mathrm{MnCl}_{2} \mathrm{~L}_{2}\right] 2 \mathrm{H}_{2} \mathrm{O}$ & 566 & 12.54 & 12.14 & 4.94 & 4.33 & 9.89 & 9.34 & 9.71 & 9.28 \\
\hline$\left[\mathrm{CoCl}_{2} \mathrm{~L}_{2}\right] \cdot 6 \mathrm{H}_{2} \mathrm{O}$ & 646 & 10.99 & 10.36 & 5.57 & 5.75 & 8,66 & 8.18 & 9.13 & 9.02 \\
\hline
\end{tabular}




\section{The study of the anti-radiation properties of tryptophanates}

To determine the presence of the radioprotective properties of the $\mathrm{Co}$ (II), $\mathrm{Mn}$ (II), $\mathrm{Cu}$ (II), $\mathrm{Zn}$ complexes with tryptophan, a test was conducted for the 30-day survival of irradiated animals. In experiments, mongrel mice weighing 20-25 g were used. The animals were withdrawn in accordance with the rules of the European Convention for the Protection of Vertebrates used for experimental and other scientific purposes.

Animals were irradiated with a gamma irradiation unit "RUHUND-20000" with a Co60 radiation source at a dose of $9.0 \mathrm{~Gy}$; the dose rate is $0.439 \mathrm{~Gy} / \mathrm{s}$. The test complexes with tryptophane were administered to the animals in an aqueous solution 30 minutes prior to irradiation at $100 \mathrm{mg} /$ $\mathrm{kg}$. To compare the radioprotective activity of the complexes tryptophan studied, a radioprotectorstandard cystamine (bis ( $\beta$-aminoethyl) disulphide) was used in the optimal radioprotective dosage of $100 \mathrm{mg} / \mathrm{kg}$, administered $30 \mathrm{~min}$ before irradiation.

Behavior monitoring and recording of animal deaths were conducted during the first hour and then the death of the animals was recorded in the next 30 days after the injection. The test results are shown in the table.

The study of the radioprotective activity of complexes of $\mathrm{Co}$ (II), $\mathrm{Mn}$ (II), Cu (II), $\mathrm{Zn}$ with tryptophan showed that they have radioprotective activity. The radioprotective activity of Co (II) complexes with tryptophan is $55 \%$, Mn (II) with tryptophan $50 \%, \mathrm{Cu}$ (II) with tryptophan $40 \%$, and $\mathrm{Zn} 35 \%$. They improve the survival and average life expectancy of lethally irradiated mice, not reaching the level of the known cystamine radioprotector, which is $80 \%$.

\section{Conclusions}

The data obtained by us testify to the prospects of using the cationic complexes of Co (II), $\mathrm{Mn}$ (II), Cu (II), Zn with tryptophan for preventive purposes and in order to prevent local radiation injuries.

This work was supported by the State Committee for Science and Technology of Belarus and the National Academy of Sciences Azerbaijan (agreement with BRFFR No. B18AZG-002)

Table 2. Action of tryptophan complexes on the survival of irradiated animals

\begin{tabular}{|l|c|c|c|}
\hline \multicolumn{1}{|c|}{ Options } & The number of mice & Survival rate, $\%$ & Life expectancy, day \\
\hline Control (distil.water) & 20 & 20 & 30 and more \\
\hline Irradiated control & 0 & 0 & $4,32 \pm 1,21$ \\
\hline Cystamine & 16 & 80 & $18,31 \pm 0,31$ \\
\hline $\begin{array}{l}\text { Co (II) complexes with } \\
\text { Tryptophane }\end{array}$ & 11 & 55 & $16,3 \pm 2,33$ \\
\hline $\begin{array}{l}\text { Mn(II) complexes with } \\
\text { Tryptophane }\end{array}$ & 10 & 50 & $12,1 \pm 2,21$ \\
\hline $\begin{array}{l}\text { Cu(II) complexes with } \\
\text { Tryptophane }\end{array}$ & 8 & 40 & $10,53 \pm 1,5$ \\
\hline $\begin{array}{l}\text { Zn complexes with } \\
\text { Tryptophane }\end{array}$ & 7 & 35 & $8,41 \pm 1,2$ \\
\hline
\end{tabular}

Note. P $<0.001$.

\section{References}

1. Gahramanova Sh.I., Azizov. I.V. Guliyeva.E.A., The effect of newly synthesized zinc complexes with amino acids on the morphophysiological indicators of wheat seedlings. Academic Journal of Western Siberia. 2014. T. 10, №5. P. 94-95

2. Gahramanova Sh. E., Suleymanov G.Z., Azizov.I.V. Influence Newly Syntesized Manganese Complexes with Amino Asids on Morphophysiological Chracteristics Wheat Germ. American International Journal of Contemporary Research. 2014. Vol. 4, No. 12. P. 58-60.

3. Mahmudov K. T., Sutradhar M., Martins L., Silva F. C, Ribera A., Nunes V. M., Marchetti F., Pombeiroa A. L., Gahramanova Sh. I., $\mathrm{Mn}$ (II) and $\mathrm{Cu}$ (II) complexes with arylhydrazones of active methylene compounds as effective heterogeneous catalysts for solvent and additive-free microwave-assisted peroxidative oxidation of alcohols. RSC Advances An international journal to further the chemical sciences. The Royal Society of Chemistry. 2015. 5. P. 25979-25987.

4. Gahramanova Sh.I., Gulieva E.A., Suleimanov G.Z., Karimova U.A., Asgarova T.Y. Interaction of manganese (II) with valine and $Я$-alanine. International Youth Scientific and Practical Conference of Students, graduate students and young "Fundamental and applied research in the field of chemistry and ecology", (Kursk September 23 - September 26, 2015). P. 29-31.5. 
5. Alam S.M., Shereen A. Effect of different levels of Zinc and Phosphorus on growth and chlorophyll content of wheat. Asian J. of plant sciences. 2002. № 3. P. 304-306.

6. Mortverdt J.J., Giordano P.M. 1969. Availability to com of zinc applied with macro nutrient fertilizers. Soil. Sc. 1969 . № 108. P. 180-187.

7. Tayyeva H., Humid U. Sh., Muhammad J. Zinc effect on grown rate, chlorophyll, protein and mineral contents of hidroponically mungbeans plant (Vigna radiata). Arabian J. of Chemistri. 2013. P. 1-7.

8. Viets F.J. Zn deficiency in the soil plant system. C. Thomas publisher. Springfield, USA, 1966. P. 90-127.

9. K. Nakamoto, Infrared and raman spectra of inorganic and coordination compounds, 5th edn. Interscience-Wiley, NewYork, 1997.

10. Gahramanova S.I., Jalaladdinov F.F., Munshieva M.K., Khudaverdiev R.A., Hamidov R.H., Muradkhanov R.M., Abdullaev A.S., Shamilov E.N., Azizov I.V. Synthesis and Investigation of Complex Compounds of Divalent Manganese, Copper, Cobalt and Zinc with Tryptophan and their Biological Activity. Int. J. Chem. Sci. Vol. 16 (3). doi: 10.21767/0972-768X.1000286.

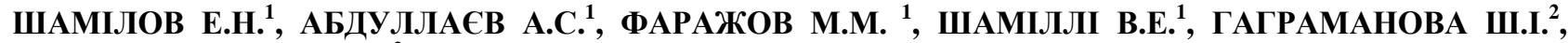
ДЖАЛАЛАДДІНОВ Ф.Ф. ${ }^{2}$

${ }^{T}$ Інститут Радіаційних Проблем Національної Академії Наук Азербайджану, Азербайджан, AZ1143, м. Баку, вул. Б. Вагабзаде, 9, e-mail: elshanshamil@ gmail.com

${ }^{2}$ Iнститут Каталізу та Неорганічної Хімії ANAS,

Азербайджан, AZ1143, м. Баку, проспект Гусейна Джавіда, 113

\section{ВЛАСТИВОСТІ СИНТЕЗУ, ХАРАКТЕРИЗАЦІЇ ТА АНТІРАДІАЦІЇ ТРИПТОФАНАТІВ КОБАЛЬТУ (II), МАНГАНЕЗА (II), КОФЕРА (II) I ЦИНКУ}

Mema. Для вивчення радіозахисної активності були отримані триптофани кобальту (II), марганцю (II), міді (II) та цинку. Методи. Склад та структуру комплексів вивчали за допомогою елементарного, термогравіметричного аналізу та ІЧ-інфрачервоної спектроскопії. Для визначення наявності радіозахисних властивостей комплексів Со (II), Mn (II), Cu (II), Zn з триптофаном було проведено тест на 30 -денну виживаність опромінених тварин. Результати. Результати термогравіметричних досліджень показали, що кінцевим продуктом термічного розпаду всіх сполук $є$ оксид металу відповідно. Метод ІЧ-спектроскопії показав, що ліганди у складі металевих (II) комплексів входять у нейтральну форму і координують комплексоутворювач через атом азоту. Результати експериментів із комплексами показали, що вони мають помітну радіозахисну активність. Радіопротекторна активність комплексів Со (II) з триптофаном становить $55 \%, \mathrm{Mn}$ (II) 3 триптофаном $50 \%, \mathrm{Cu}$ (II) $з$ триптофаном $40 \%$ та Zn 30\%. Вони покращують виживання та середню тривалість життя смертельно опромінених мишей, не досягаючи рівня відомого радіопротектора цистаміну, який становить $80 \%$. Висновки. Отримані нами дані свідчать про перспективи використання комплексів Сo (II), $\mathrm{Mn}$ (II), $\mathrm{Cu}$ (II), Zn з триптофаном у профілактичних цілях для запобігання місцевих радіаційних травм.

Ключові слова: триптофанометалеві комплекси, ІЧ-спектроскопія, термогравіметрія, складні сполуки, радіозахисні властивості. 